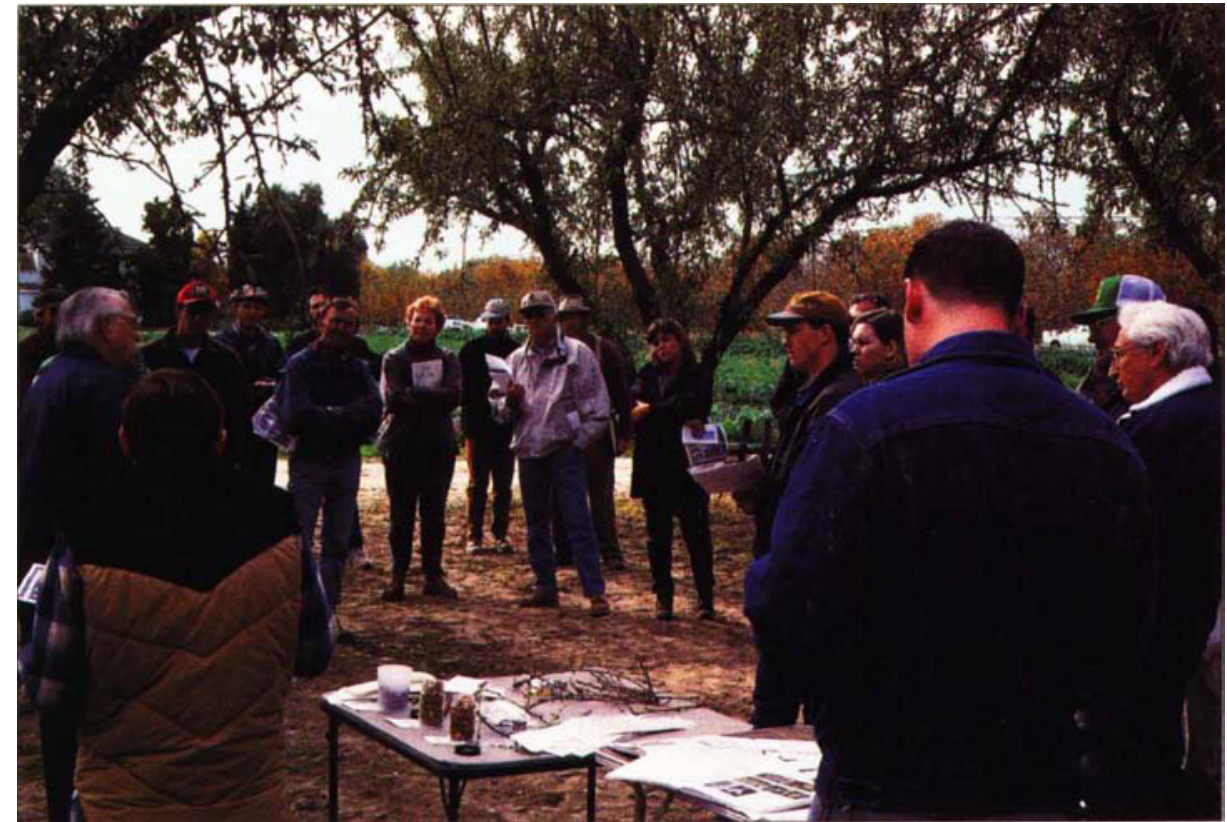

\section{BIOS and conventional almond orchard management compared}

\author{
Walt J. Bentley 」 Lonnie Hendricks 」 Roger Duncan \\ Cressida Silvers 」 Lee Martin 」 Marcia Gibbs 」 Max Stevenson
}

Conventional almond growers in Merced and Stanislaus counties who use organophosphate, carbamate and pyrethroid insecticides were compared with participants in the Biologically Integrated Orchard Systems (BIOS) program, who do not use these broadspectrum insecticides. The results demonstrated consistent but not significantly lower infestation by navel orangeworm and peach twig borer for growers who used broad-spectrum sprays. Infestation by ants resulted in the most consistent difference between the two management practices, with significantly less damage when broad-spectrum sprays were used. The differences in overall pest damage were relatively minor, but the variation
Participants in the Biologically Integrated Orchard Systems (BIOS) program attend field days, such as this one in Hopeton, to learn how to avoid the use of broadspectrum insecticides. In a 3-year study, the authors compared the effectiveness of pest management techniques, and the levels of pests and their parasitoids, in BIOS and conventional almond orchards.

T 1988, UC farm advisor Lonnie 1 Hendricks began a study in which he evaluated the pest management practices of two brothers, Glenn and Ron Anderson, who farmed almonds in Merced County. One managed insects and weeds with a conventional, broad-spectrum pesticide approach. The other used no insecticides, planted a cover crop and relied minimally on herbicides. Hendricks monitored infestation from peach twig borer (Anarsia lineatella) and navel orangeworm (Aniyelois transitella) over a 6-year period. He found no differences in infestation due to either of these pests. In fact, damage in the unsprayed orchard was often lower than in the sprayed orchard (Hendricks 1995).

Almond production in 2000 had increased to 500,000 acres from 90,654 acres in 1990. Although some almond growers in Merced, Stanislaus and Modesto counties, such as Ray Eck and Glenn Anderson, had been moving away from using organophosphate, carbamate and pyrethroid insecticides for many years, the results of the Anderson study intrigued others who wished to reduce inputs for insect pest management. These materials are hazardous to pesticide applicators and pose risks to farmworkers. They have been found in streams, rivers and fog. The use of organophosphate, carbamate and pyrethroids can also cause web-spinning spidermite problems, which are costly to control.

From this grower interest was born the almond Biologically Integrated Orchard Systems (BIOS) program, initiated in 1993 by a nonprofit organization, Community Alliance with Family Farmers (CAFF). Programs such as BIOS emphasize less reliance on broad-spectrum materials and greater reliance on cultural, biological and 
nondisruptive pesticides (Swezey and Broome 2000). However, many growers still want the security of broadspectrum insecticides in managing almond pests. The perceived risks of damage from omitting sprays are more than they are willing to accept.

In 1996, we designed an intensive 3-year study to evaluate the elimination of broad-spectrum insecticides in almonds, on a larger scale than the Hendricks study. Information on pest and beneficial insect dynamics as well as nut infestation was gathered from orchards that followed two different pest management approaches. A BIOS approach, not using disruptive sprays, was compared with a more conventional pest-management system that used sprays. Also, the BIOS growers planted cover crops, while only two of the conventional growers used them (both low-grow mixture). In addition, Goniozus legneri, a navel orangeworm parasitoid, was periodically released in four of the unsprayed BIOS orchards at least once during the study.

In this study, the term "conventional orchard" describes the use of a dormant spray or at least one seasonal insecticide spray per growing season. A national IPM study reported that $92 \%$ of California almond growers used broad-spectrum dormant sprays in 1983, while more than $78 \%$ used May sprays and $81 \%$ used hullsplit sprays (Rajotte et al. 1987). Based on this information, growers who applied these sprays can be called "conventional."

\section{Orchard comparisons}

Seven BIOS and seven conventional almond orchards were initially selected and monitored throughout the season, beginning in 1996 (table 1). Two orchard comparisons were located in Stanislaus County and five in Merced County. Each of the orchard comparisons was composed of the Nonpareil cultivar, which is quite susceptible to navel orangeworm. Nonpareil (NP) is currently the predominant and most desirable almond cultivar because of its mild taste and the ease of processing it. In each of these comparisons, except for comparison 3 , the orchards were located side by side.
Comparisons 2, 4 and 5 were part of the same orchard. The orchards in comparison 3 were approximately 1 mile apart. Orchard 7 used no insecticide applications in the conventional plots and was not included in the comparison of conventional versus BIOS, but was used for the winter sanitation portion. The only difference in management practices in orchard 7 was the planting of a low-grow cover crop in the BIOS side. The conventional plot side had a resident vegetation cover.

Spray protocols. Each of the conventional sites received either dormant oil and organophosphate spray (usually chlorpyrifos but sometimes phosmet) for a dormant spray, or a hullsplit organophosphate spray in July of each year, or both. Two of the

\begin{tabular}{|c|c|c|c|c|c|}
\hline \multicolumn{6}{|c|}{$\begin{array}{l}\text { TABLE 1. Comparison of almond orchards cultivated with } \\
\text { Biologically Integrated Orchard Systems (BIOS) and conventional methods, 1996-1999 }\end{array}$} \\
\hline Grower/county & Acreage & Cultivar & Age & Cover crop* & Sanitation \\
\hline $\begin{array}{l}\text { BIOS } 1 \\
\text { Stanislaus }\end{array}$ & 19 acres & $\begin{array}{l}66 \% \text { NP, } \\
33 \% \text { Merced }\end{array}$ & 23 years & $\begin{array}{c}\text { Rich mix, low grow; } \\
\text { insectary every } \\
\text { 10th row }\end{array}$ & No \\
\hline $\begin{array}{l}\text { Conventional } 1 \\
\text { Stanislaus }\end{array}$ & 5 acres & $\begin{array}{l}66 \% \text { NP, } \\
33 \% \text { Price }\end{array}$ & 14 years & None & $\begin{array}{l}\text { Knocking, } \\
\text { disking }\end{array}$ \\
\hline $\begin{array}{l}\text { BIOS } 2 \\
\text { Stanislaus }\end{array}$ & 10 acres & $\begin{array}{l}50 \% \text { NP, } \\
36 \% \text { Price, } \\
14 \% \text { Neplus }\end{array}$ & $\begin{array}{l}10-11 \\
\text { years }\end{array}$ & $\begin{array}{l}\text { Rich mix with } \\
\text { grains, cereals }\end{array}$ & No \\
\hline $\begin{array}{l}\text { Conventional } 2 \\
\text { Stanislaus }\end{array}$ & 5 acres & $\begin{array}{l}50 \% \text { NP, } \\
36 \% \text { Price, } \\
14 \% \text { Neplus }\end{array}$ & $\begin{array}{l}10-11 \\
\text { years }\end{array}$ & $\begin{array}{l}\text { Half rich mix, } \\
\text { with vetch }\end{array}$ & No \\
\hline $\begin{array}{l}\text { BIOS } 3 \\
\text { Merced }\end{array}$ & 8 acres & $\begin{array}{l}66 \% \text { NP, } \\
33 \% \text { Merced }\end{array}$ & 29 years & Low grow & Poling \\
\hline $\begin{array}{l}\text { Conventional } 3 \\
\text { Merced }\end{array}$ & 20 acres & $\begin{array}{l}66 \% \text { NP, } \\
33 \% \text { Merced }\end{array}$ & $15+$ years & None & Poling \\
\hline $\begin{array}{l}\text { BIOS } 4 \\
\text { Merced }\end{array}$ & 12 acres & $\begin{array}{l}50 \% \text { NP, } \\
50 \% \text { Carmel }\end{array}$ & 12 years & Low grow & No \\
\hline $\begin{array}{l}\text { Conventional } 4 \\
\text { Merced }\end{array}$ & 25 acres & $\begin{array}{l}50 \% \text { NP, } \\
50 \% \text { Carmel }\end{array}$ & 12 years & $\begin{array}{l}\text { Resident vegetation, } \\
\text { mowed }\end{array}$ & No \\
\hline $\begin{array}{l}\text { Blos } 5 \\
\text { Merced }\end{array}$ & $\begin{array}{l}20 \text { acres } \\
\text { (out of } 91 \text { ) }\end{array}$ & $\begin{array}{l}50 \% \text { NP, } \\
50 \% \text { Carmel }\end{array}$ & 17 years & Low grow & Yes \\
\hline $\begin{array}{l}\text { Conventional } 5 \\
\text { Merced }\end{array}$ & $\begin{array}{l}20 \text { acres } \\
\text { (out of } 83 \text { ) }\end{array}$ & $\begin{array}{l}50 \% \text { NP, } \\
50 \% \text { Price }\end{array}$ & 17 years & Low grow & Yes \\
\hline $\begin{array}{l}\text { BIOS } 6 \\
\text { Merced }\end{array}$ & 40 acres & $\begin{array}{l}55 \% \text { NP; } \\
\text { Merced, Price } \\
\text { Mission, Fritz }\end{array}$ & 35 years & $\begin{array}{l}\text { Self-seeded } \\
\text { rich mix }\end{array}$ & Yes \\
\hline $\begin{array}{l}\text { Conventional } 6 \\
\text { Merced }\end{array}$ & 20 acres & $\begin{array}{l}50 \% \text { NP, } \\
25 \% \text { Neplus, } \\
25 \% \text { Mission }\end{array}$ & 22 years & None & No \\
\hline $\begin{array}{l}\text { BIOS } 7 \\
\text { Merced }\end{array}$ & 5 acres & $\begin{array}{l}50 \% \text { NP; } \\
\text { Mission } \\
\text { Merced, Neplus }\end{array}$ & 1972 & Low grow & No \\
\hline $\begin{array}{l}\text { Resident vegetation } 7 \\
\text { Merced }\end{array}$ & 76 acres & $\begin{array}{l}50 \% \text { NP; Price, } \\
\text { Mission, Merced }\end{array}$ & 1977 & Resident vegetation & No \\
\hline
\end{tabular}

Merced

Mission, Merced

- Cover crop mixes were developed by Robert Bugg and the UC Sustainable Agriculture Research and Education Program (SAREP), and are available from Lohse Mill, Inc. in Artois, Calif. The low-grow mix includes common vetch, burr medic, crimson clover, subclovers and blando brome, and is seeded at 40 pounds per acre. The annual insectary blend includes subterranian clovers, common vetch, clovers, rye, triticale, barley, bee phacelia, coriander, sweet alyssum, tidy tips, celery, bishop's weed and toothpick weed, and is seeded at 12 pounds per acre. The rich mix Includes vetches, barley, oats, burr bedic and subclovers, and is seeded at 65 pounds per acre. Resident vegetation includes naturally occurring weeds, which are not seeded. 


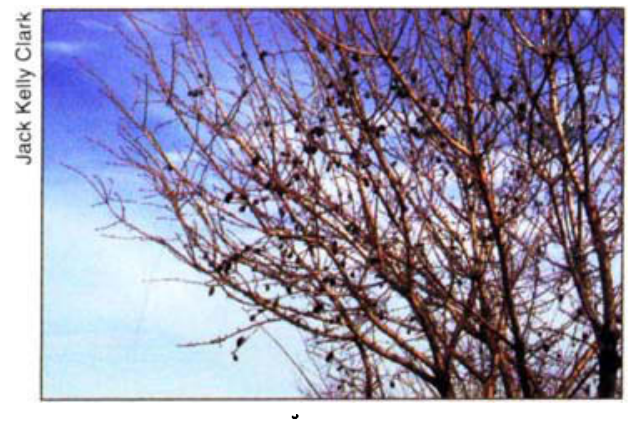

conventional orchard comparisons were not treated in 1997, and data from these two sites were not used during 1997. The conventional comparison in these two sites was sprayed in 1996 and 1998. The BIOS orchards did not receive any broad-spectrum sprays during the study period (Santer 1995). Some were treated with Bacillus thuringiensis $(\mathrm{Bt})$ at bloom to manage peach twig borer, and four received releases of $G$. legneri for navel orangeworm. Navel orangeworm and peach twig borers feed on the nut meats, leaving excrement, webbing or body parts; damaged nuts are more prone to aflatoxin contamination. None of the BIOS orchards received dormant sprays or oil-only dormant treatments.

Mummy nuts. During the winters of 1996, 1997 and 1998, we selected 10 to 20 trees in each orchard and counted the number of unharvested mummy nuts. Mummy nuts serve as the wintering site for navel orangeworm: when they are removed, so is the pest. (The unharvested mummies are nuts that did not come off the tree at harvest.) This information was used to evaluate the influence of winter nut abundance on subsequent navel orangeworm infestation. Each winter, we collected a sample of 50 to 100 nuts from trees and quantified navel orangeworm infestation and parasitism. As many mummy nuts as possible were collected from the tree (or from the ground if necessary) and examined for navel orangeworm and parasitoids. Navel orangeworm were also held in storage to document emergence of $G$. legneri.

Three of the conventional orchards were not established early enough in 1996 to take mummy counts. However, mummy counts were taken from all BIOS orchards in all 3 years. In addition to the seven orchards in the
Mummy nuts that remain on almond trees after harvest can serve as a wintering site for the navel orangeworm, an important almond pest. The authors found that winter sanitation - the removal of mummy nuts to two or fewer per tree - was an effective strategy for controlling navel orangeworm.

comparison, we counted mummy nuts in 44 BIOS orchards in 1996 to evaluate winter survival of $G$. legneri where disruptive sprays were not used. None of the 44 orchards used dormant or inseason organophosphate or carbamate sprays.

Pest monitoring. In 1996, all of the orchards were monitored for peach twig borer with two Pherocon 1c traps and Consep pheromone dispensers in each orchard, changed every month. In 1997 and 1998, three traps were used in each orchard. Navel orangeworm dynamics were monitored in
1996 with two black navel orangeworm egg traps baited with almond press cake and almond oil, changed monthly during the growing season or when they became wet. Three traps were used in 1997 and 1998. San Jose scale was monitored with two Pherocon tent traps baited with Trece San Jose scale pheromone dispensers, changed monthly. Three San Jose scale traps were used in 1997 and 1998. Feeding by San Jose scale results in the death of fruit wood and can eventually kill the tree.

At harvest 500 nuts were randomly collected from each orchard, with no more than 20 nuts taken from beneath one tree. These were evaluated for damage from navel orangeworm, peach twig borer and ants. (Both species of ants invade nuts, chewing holes in them and eventually consuming the meat.) When navel orangeworms were found, they were exam-

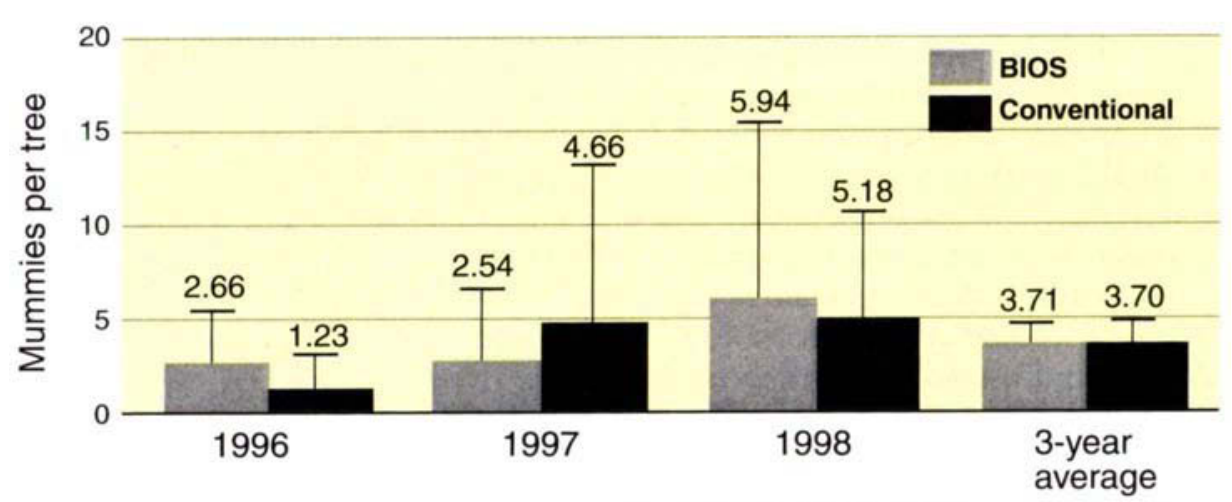

Fig. 1. Average number of winter mummies per tree in six BIOS and six conventional almond orchards.

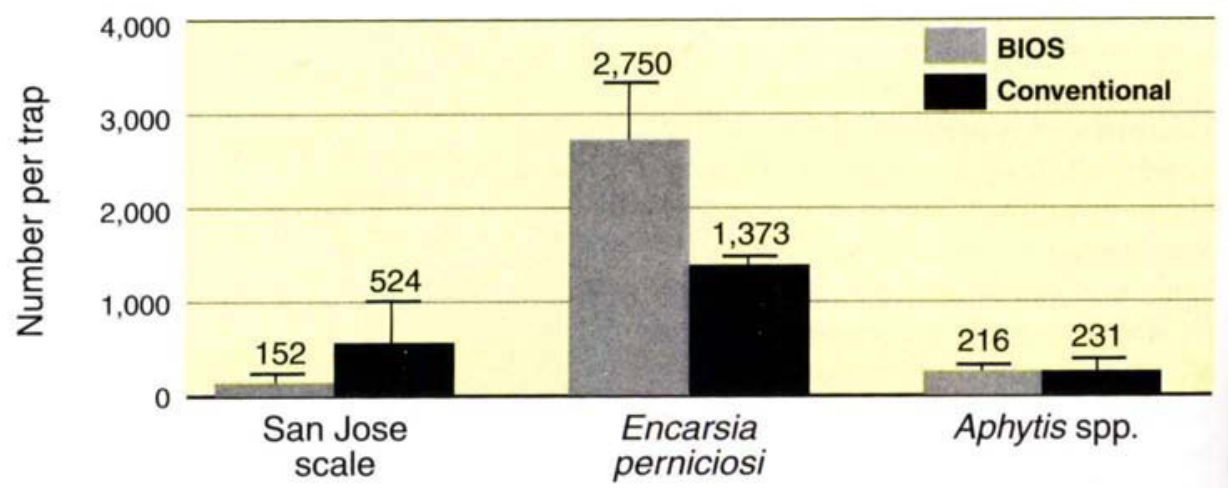

Fig. 2. Three-year summary of abundance of San Jose scale and its parasitoids, Encarsia pernicoiosi and Aphytis spp., per trap per year, in six BIOS and six conventional almond orchards. 
ined and held in glass vials for parasite emergence.

\section{Sanitation and navel orangeworm}

The first objective of the study was to investigate the relationship between winter sanitation, which involves removing mummy nuts from trees, and navel orangeworm abundance, as well as the impact of sanitation on infestations in unsprayed orchards (fig. 1).

The data from 1996 does not include one BIOS orchard that had a count of 113 mummies per tree; however, that orchard was included for harvest infestations. If that orchard were included, the BIOS mummy count would average 21 per tree. Excluding the mummy count from orchard 1 resulted in 2.66 mummies per tree in the BIOS orchards and 1.23 in the conventional (only four orchards).

In 1997, all six comparison orchards were included, and the average mummy count was 2.54 in BIOS and 4.66 in conventional orchards. The 1998 counts were the highest of the 3 years, with an average of 5.94 in BIOS and 5.18 in conventional. The 3-year average mummy loads were 3.7 in both the BIOS and conventional orchards. Both groups of growers removed mummy nuts during the winter. UC pest management guidelines state that two or fewer mummies per almond tree is the key to managing navel orangeworm (Barnes et al. 1985; Zalom et al. 1984). Only the four conventional orchards in 1996 averaged two or fewer mummies per tree.

The seven BIOS orchards (including the nonsprayed orchard comparison site) were categorized by the number of mummies per tree in each of the 3 years. The categories used were orchards with two or fewer mummies, or more than two per tree during the winter. At harvest, nut infestation was determined for the orchards that fell into the two groups. In 1997, only one of the orchards averaged more than two mummies. (Interestingly, the lowest infestation from navel orangeworm and the smallest difference between BIOS and conventional infestation was in 1997.) This sample was too small to use in the statistical analysis.
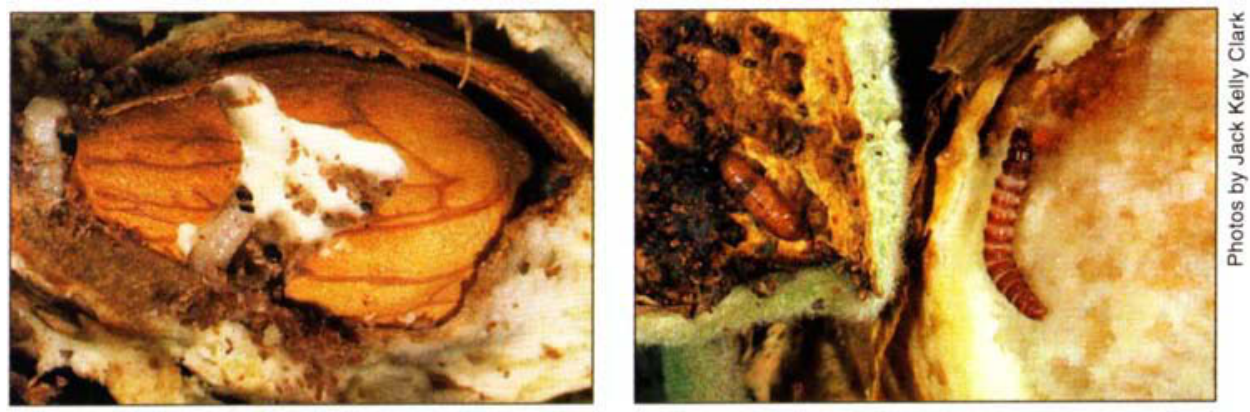

Navel orangeworm, left, and peach twig borer, right, feed on almonds. The abundance of both pests was not significantly different in BIOS and conventional orchards.

Over the 3-year period the average infestation in orchards with more than two mummies was $3.90 \%$, while those two or fewer was $2.26 \%$. (Growers receive bonus payments from processors for lower infestation levels.) This finding validates previous work showing the benefits of winter sanitation in reducing infestation by navel orangeworm. When the mummy counts from each of the BIOS orchards were pooled over the 3-year period and a regression analysis performed, a highly significant $(P<0.0001) \mathrm{R}^{2}$ of 0.582 and an $R$ value of 0.766 resulted ( 23 orchards)

\section{Sanitation and parasitoids}

The second study objective was to investigate the relationship between winter sanitation and the abundance of overwintering G. legneri, an external wasp parasitoid.

In a separate evaluation, $44 \mathrm{BIOS}$ orchards (including the six in the $\mathrm{BIOS}$ /conventional comparison) were monitored for the presence of navel orangeworm and $G$. legneri in unharvested mummies in 1996. A total of 2,720 mummies were examined and $379(13.93 \%)$ were infested with navel orangeworm. Four navel orangeworm $(1.1 \%)$ from these collections were parasitized. Of the four parasitoids, two were G. legneri and two were Copidosoma plethorica. None of the six intensively monitored BIOS orchards had parasitoids in the infested mummy nuts.

In 1997, only four BIOS orchards were sampled. From 400 nuts, 32 nuts $(8 \%)$ were infested with navel orangeworm. A single G. legneri was found (3.1\% of infested nuts). In 1998, eight orchards were sampled for mummy nuts. A total of 595 mummies were ex- amined and 111 navel orangeworm were found $(18.7 \%)$. No parasitoids were found in 1998. Over the 3-year period, 522 navel orangeworm were sampled from unharvested mummy nuts in unsprayed orchards. Only five parasitoids (three G. legneri and two C. plethorica) were found. The results indicate that winter survival of $G$. legneri was very low in Merced and Stanislaus counties.

\section{San Jose scale abundance}

The third study objective was to evaluate the abundance of San Jose scale and its associated parasitoids in BIOS and conventional orchards.

San Jose scale is an increasingly damaging pest in many almondgrowing areas of California. However, almond growers in Stanislaus, Merced and Madera counties have reported little tree damage from this pest. Our

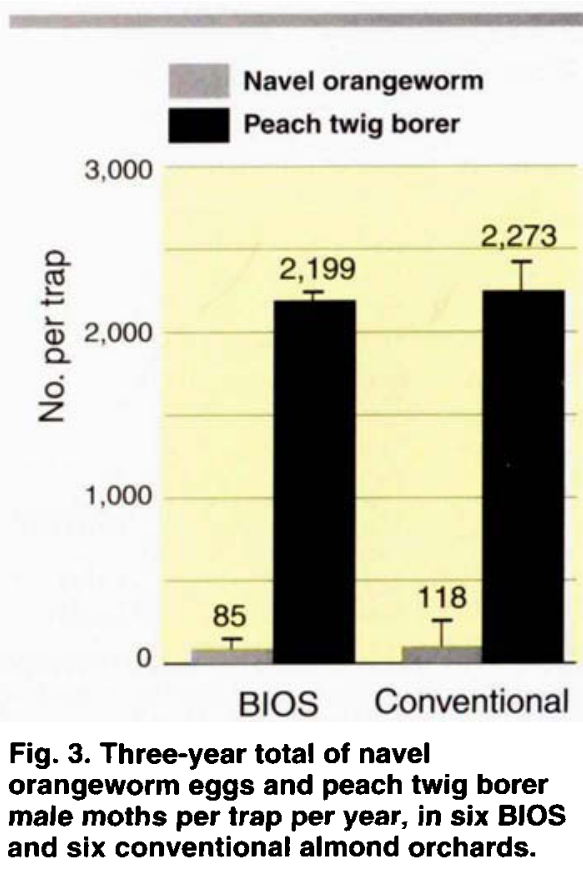


study results indicate that San Jose scale is not a common problem in either BIOS or conventional orchards in these counties. The abundance of San Jose scale males trapped in San Jose scale sticky traps is correlated to crawler abundance (Bentley et al. 1998).

The numbers of San Jose scale trapped in this study were remarkably low (compared with previous trapping data in heavily and moderately infested orchards), with only one of the BIOS orchards showing symptoms of scale damage (limb death in the lower canopy). This became evident during the third year of the study, when traps in that BIOS orchard averaged 707 male San Jose scale during the season.
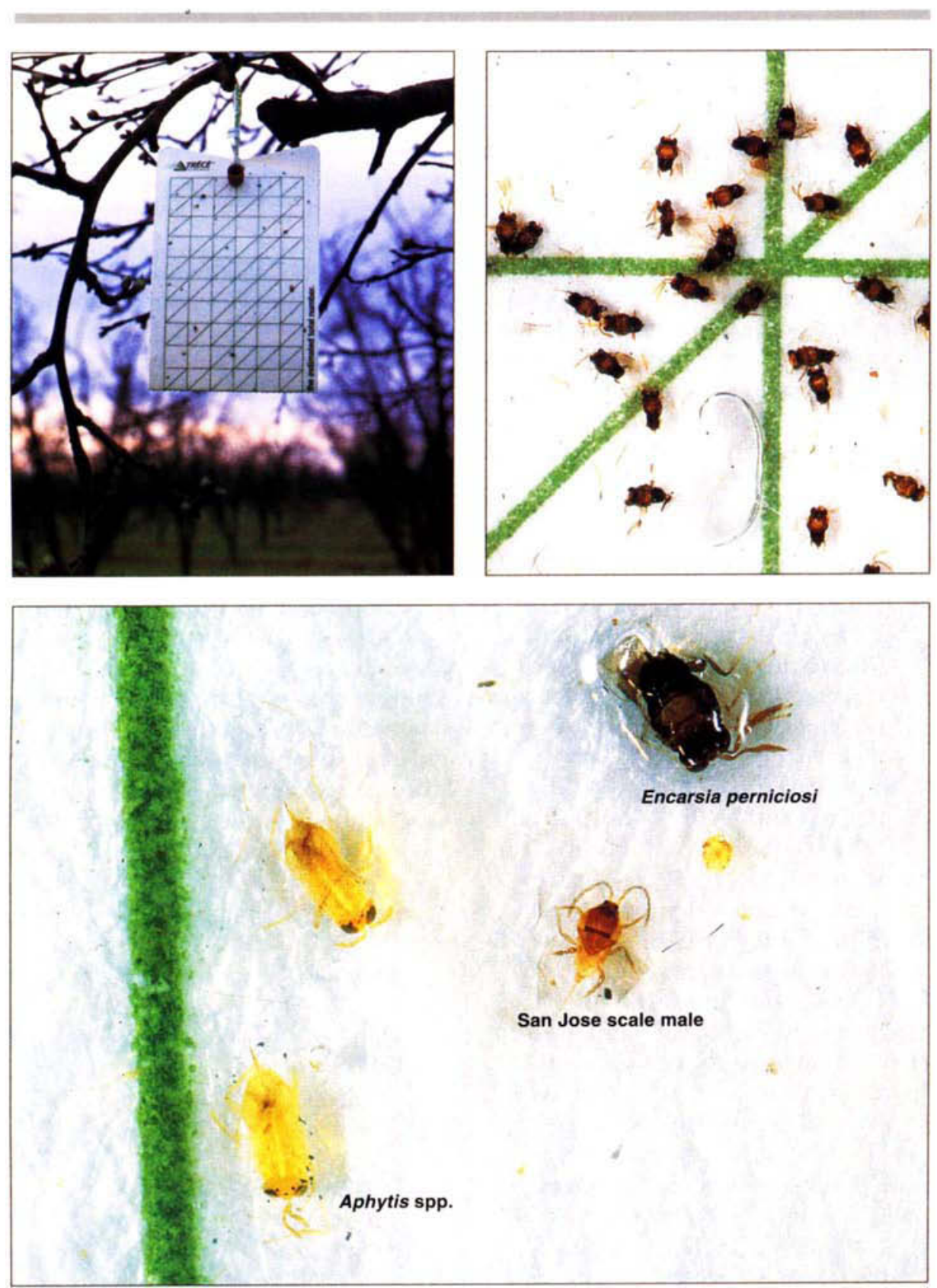

San Jose scale has become an increasingly damaging pest in many almond-growing regions of California. However, the numbers trapped in the study orchards, located in Merced and Stanislaus counties, were very low. Clockwise from top left, Sticky traps are used to monitor San Jose scale males; the numbers of a key San Jose Scale parasitoid, Encarsia perniciosi, were significantly higher in the BIOS orchards; the abundance of another San Jose scale parasitoid, Aphytis spp., did not vary significantly between BIOS and conventional orchards.
No other BIOS orchard trapped more than 104 San Jose scale. The number of males caught (monitoring three flights) per trap per season averaged 152 over the 3 -year period in the unsprayed BIOS orchards and 524 in the sprayed conventional orchards (fig. 2). Because of the high level of variation in trap catches, there was no statistical difference in the numbers of scale between BIOS and the conventional orchards.

There was a significant difference $(P<0.12$, Fisher's protected LSD) between the numbers of Encarsia perniciosi trapped in the BIOS and conventional orchards. E. perniciosi is a key insect parasitoid of San Jose scale and it appears to be a key factor in regulating scale populations. An average of 2,750 E. perniciosi were trapped in the BIOS orchards and 1,373 in the conventional orchards.

There was no difference between treatments in the numbers of another San Jose scale parasitoid, Aphytis spp., trapped on pheromone sticky traps. An average of 231 Aphytis spp. per trap were found in the conventional orchards and 216 per trap in the BIOS orchards. Aphytis spp., an internal wasp parasitoid, tended to be trapped very early and very late in the growing season, with few trapped during June and July. Although E. perniciosi seems to be a more important parasitoid than Aphytis spp., this may not be the case. Aphytis spp. may be as abundant but not respond to the pheremone attractant (impregnated in the rubber septa) as well as E. perniciosi. We are currently conducting research on the actual levels of scale parasitism.

\section{Orangeworm and borer abundance}

The fourth study objective was to monitor navel orangeworm and peach twig borer throughout the growing season, to determine whether there are major differences in abundance and seasonal activity based on the use of broad-spectrum sprays.

The abundance of navel orangeworm, based on egg counts found on navel orangeworm egg traps, was very low in both BIOS and conventional or- 

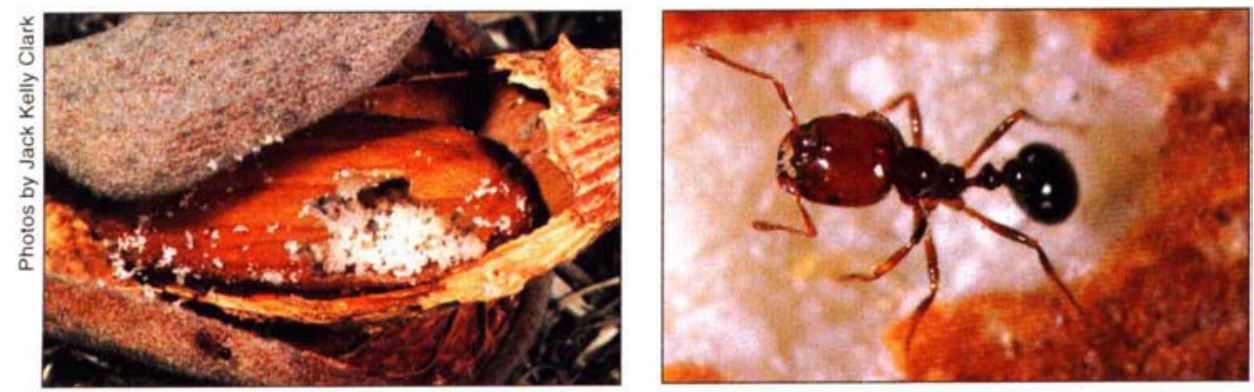

The Southern fire ant damages almonds by eating the nuts. Ant damage was slightly higher in the BIOS orchards $(1.24 \%)$ compared with the conventional orchards $(0.67 \%)$.

chards. A total of 85 eggs per trap per season were found in the BIOS orchards, compared with 118 eggs per trap per season in the conventional orchards (fig. 3). There was no significant difference in the number of eggs deposited on egg traps between the two comparisons over the 3-year period. The initiation of navel orangeworm oviposition on black egg traps was identical between the BIOS and conventional orchards, with no obvious shifts in periods of egg deposition.

The abundance of peach twig borer, based on pheromone trap counts, was not significantly different between the BIOS orchards and the conventional orchards (fig. 3). Also, as with the navel orangeworm, peach twig borer flight dynamics were not different between the two treatments. The beginning of male flight in each of the three generations in each of the 3 years was identical in the BIOS and conventional orchards.

\section{Harvest damage}

The fifth study objective was to assess damage due to ants, navel orangeworm and peach twig borer at harvest in BIOS and conventional orchards and to tabulate differences in navel orangeworm parasitism between the two practices.

Based on the management practices we studied, damage due to ants, navel orangeworm and peach twig borer were of greatest importance to almond farmers (fig. 4). There was no significant difference between BIOS and conventional pest-management practices in infestation due to navel orangeworm, peach twig borer, or total damage. During the 3 years, damage by navel orangeworm was least in the conventional orchards, and the variation among growers was also least. For instance, navel orangeworm infestation for the BIOS growers was $4.46 \%$ in $1996,2.48 \%$ in 1997 , and $3.13 \%$ in 1998. Damage by navel orangeworm was $2.23 \%, 2.16 \%$ and $2.67 \%$ in the conventional orchards for the same years. The variation in damage was less in the conventional than in the BIOS orchards. The inconsistency of low navel orangeworm infestation is one key reason why growers are hesitant to reduce their chemical usage.

The navel orangeworm parasitoid, G. legneri, was also sampled when we examined nuts for navel orangeworm infestation at harvest. Only eight parasitized larvae were found over the 3-year period in the BIOS orchards. During 1996, 197 navel orangeworm were collected and held for parasitism, and four $(2 \%)$ were parasitized by $G$. legneri; during 1997, 87 navel orangeworm were held and four $(4.6 \%)$ parasitized. No parasitoids were recovered during 1998 from 125 navel orangeworm. During 1996, navel orangeworm infestation in the two orchards with parasitoids present was $4.8 \%$ and
$4.4 \%$; in 1997 , it was $6.2 \%$ and $5 \%$. No G. legneri were found in navel orangeworm sampled from the conventional orchards, presumably because they were killed by insecticide treatments.

Although flight by peach twig borer was quite high in all orchards, damage by this pest was minimal. The 3-year peach twig borer infestation averaged $0.43 \%$ in the BIOS orchards and $0.55 \%$ in the conventional. There was no significant difference in peach twig borer damage as influenced by pest management practice. Peach twig borer damage never averaged more than $1 \%$. This is one of the key pests that almond growers attempt to manage with dormant sprays; it appears to pose less of a risk than believed.

Ant damage (Solenopsis xyloni and Tetramorium caespitum), although intermediate between damage from navel orangeworm and peach twig borer, was significantly less $(P<0.18$, Fisher's protected LSD) in the conventional than the BIOS orchards. The 3-year average damage due to ants was $1.24 \%$ in BIOS and $0.67 \%$ in conventional orchards.

Finally, total insect damage was not significantly different between the two pest management practices. Total damage averaged $5.03 \%$ in the BIOS and $3.57 \%$ in the conventional orchards. Such differences in total damage rates are considered important when infestations are greater than $5 \%$, the level where processing is more costly and growers receive less money.

Fig. 4. Three-year summary of percent insect infestation in nuts sampled in six BIOS and six conventional almond orchards.

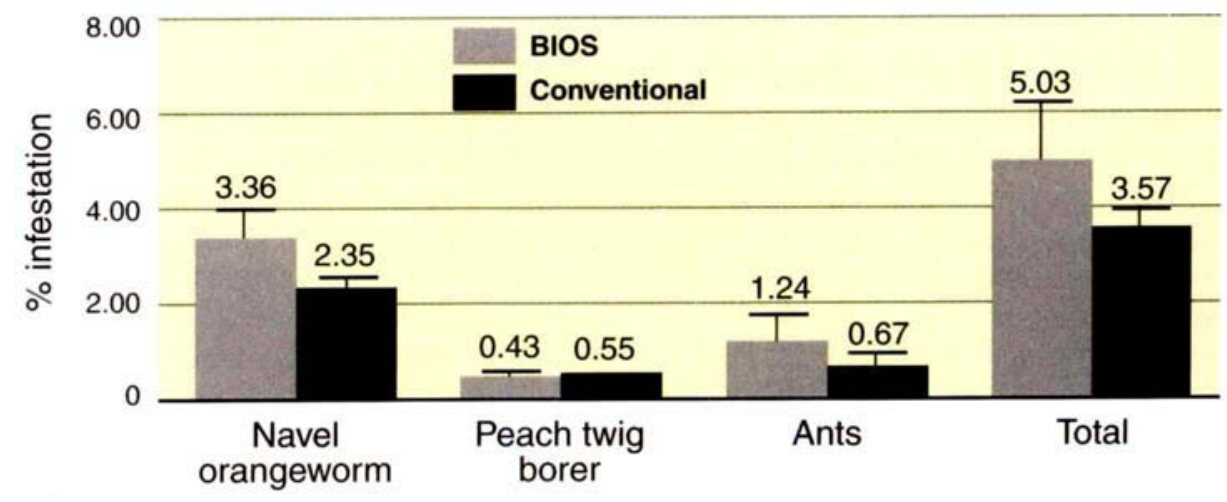

CALIFORNIA AGRICULTURE, SEPTEMBER-OCTOBER 2001 


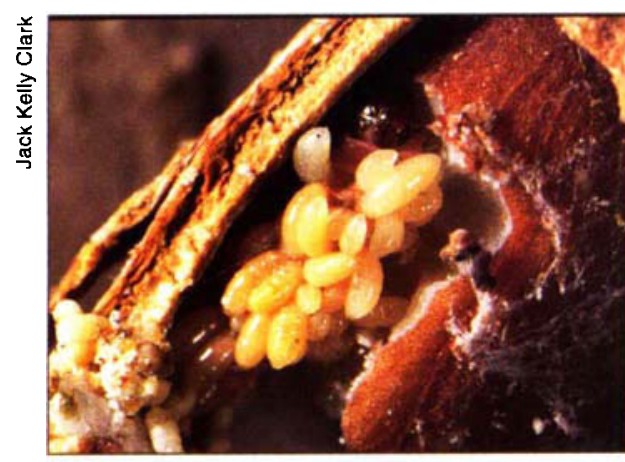

Goniozus legneri, a navel orangeworm parasitoid, was periodically released in four of the BIOS orchards studied. Navel orangeworm found in mummy nuts were sampled for G. legneri; its winter survival was low, with only three parasitoids identified in 3 years.

\section{Monitoring of infestations}

Navel orangeworm and parasi-

toids. The results of the winter sanitation investigation indicate that survival of the navel orangeworm parasitoid, G. legneri, was poor, even in unsprayed orchards where mummy loads were quite high. One of the BIOS orchards averaged 113 mummies per tree in 1996 and no wintering parasitoids were found, even though $10.4 \%$ of mummies were infested with navel orangeworm. Alternatively, the practice of winter sanitation resulted in a consistent reduction of navel orangeworm infestation at harvest. Based on these findings, the practice of not removing and destroying mummy nuts, in order to preserve $G$. legneri, cannot be recommended. Where $G$. legneri was active at harvest, infestation from navel orangeworm was relatively high, ranging from $4.4 \%$ to $6.8 \%$.

San Jose scale and parasitoids. The results of the scale monitoring indicate relatively low infestation in all but one of the test orchards. This was a BIOS orchard that averaged 707 male San Jose scale per trap per season and only 564 E. perniciosi. The use of pheromone traps can help almond growers track the abundance of male flyers. More importantly, these same San Jose scale pheromone traps can allow growers and pest control advisers to detect the presence of key scale parasitoids such as E. perniciosi and Aphytis spp. By integrating the information gathered from traps with vi- sual symptoms on the trees, growers can reduce the use of annual dormant sprays as a means of preventing San Jose scale damage. Also, the presence of parasitoids in orchards should give growers more confidence in managing scale with horticultural oils during the dormant season, thereby eliminating the use of broad-spectrum sprays.

In this study, orchards using organophosphate sprays at hullsplit averaged significantly fewer $E$. perniciosi and more San Jose scale than growers not using them. It is clear that not all almond orchards in Merced and Stanislaus counties require annual dormant sprays to manage San Jose scale and that the abundance of $E$. perniciosi can be enhanced by not spraying with organophosphate or carbamate insecticides.

Pest abundance and damage. In the Hendricks study (1995), a difference in the initial abundance of pests in orchards could account for greater damage in the sprayed compared to unsprayed orchard. This is particularly true if there is a major difference in infestations. Pest abundance was not measured in that study. Also, it is possible that the dynamics of pest populations could be influenced by sprays or beneficial arthropod activity, resulting in pest activity at different stages of nut susceptibility. In our study, the season-long monitoring of navel orangeworm and peach twig borer in the orchards revealed no difference in the abundance of navel orangeworm eggs or peach twig borer males.

Even though neither trapping method we used is considered a strong indicator of damaging populations, they are indicators of relative abundance and periods of sexual activity for both species. For instance, trapping of the first male peach twig borer indicates that moths are present, and the timing of sprays can be based on the greatest abundance of small worms (Zalom et al. 2001). We were not able to detect any difference in the development of navel orangeworm or peach twig borer flight initiation between the two management practices. Of particu- lar interest was the lack of a difference in the numbers of peach twig borer between the almond growers using the dormant and growing-season sprays with those not using such sprays. Based on the pheromone trapping data, we can assume that populations of both pests are equally present with both management practices.

\section{Overall damage levels low}

Navel orangeworm annually accounted for the greatest amount of nut damage, averaging $3.36 \%$ in the BIOS orchards and $2.35 \%$ in the conventional orchards. An average difference of $1 \%$ would appear to be of minor importance when considering the cost of damage in relation to the expense of control, unless the grower receives a bonus payment because infestation levels are kept below $2 \%$. Even though the difference in navel orangeworm was not significant, the variation in infestation was usually greatest in the BIOS orchards. For example, BIOS grower 1 experienced $14 \%$ navel orangeworm infestation in 1996 and $6.2 \%$ navel orangeworm infestation in 1997. The greatest levels of navel orangeworm damage in the conventional comparison were $6.2 \%$ in 1996 , $9 \%$ in 1997 , and $8.2 \%$ in 1998 .

The damage from peach twig borer was minimal in each of the years studied, and was never greater than $1 \%$. Although most almond growers consider damage from peach twig borer an annual problem, it was not a problem during this study. If peach twig borer infestation varies widely from year to year, almond growers could move away from using organophosphate, carbamate and pyrethroid sprays during the dormant season by predicting the severity and using lessdisruptive pesticides such as $B t$ and spinosad.

Ant damage was significantly lower in the conventional orchards than the BIOS. Although relatively low when compared to navel orangeworm infestation, individual BIOS growers did experience economic damage from ants $(5.4 \%$ by BIOS grower 6 in 1996). We are currently evaluating thresh- 

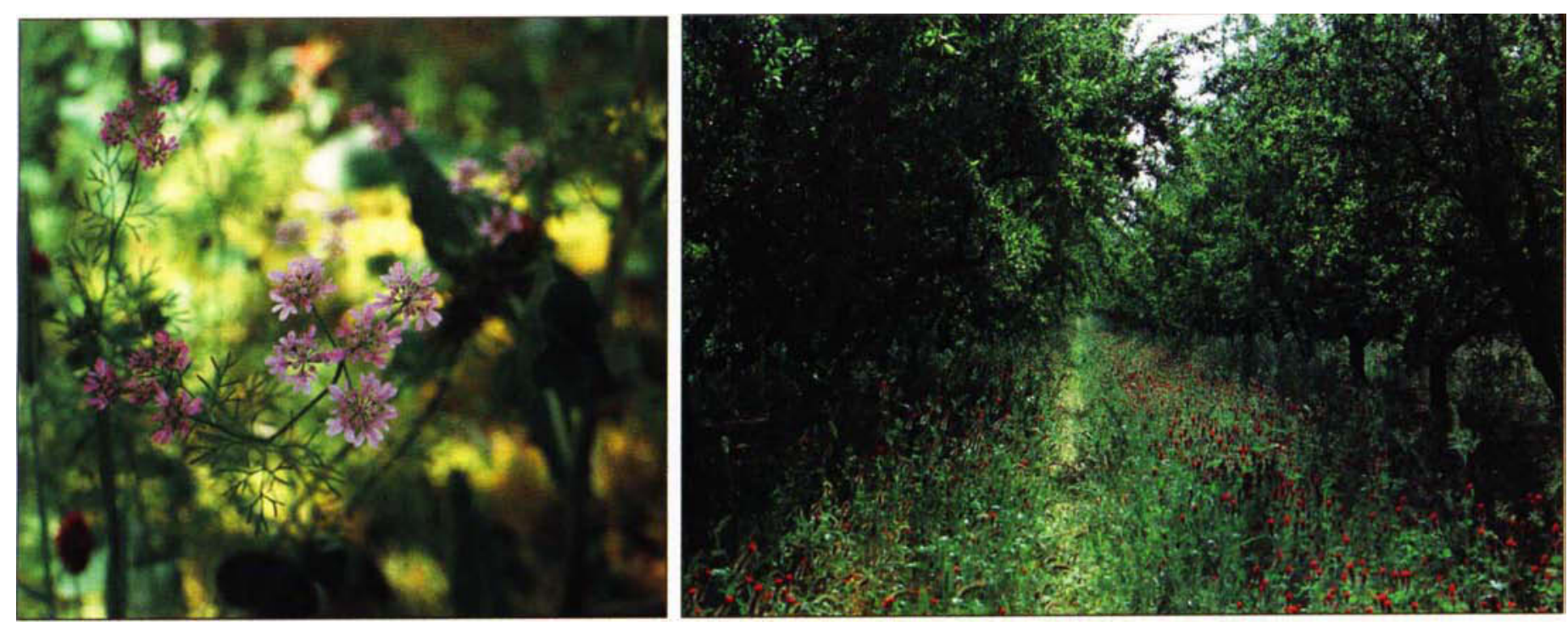

Both BIOS and conventional growers used cover crops, above, during the study. Total insect damage levels did not vary significantly between the two pest management practices, but BIOS damage levels were slightly higher. Growers may still be hesitant to risk higher levels of crop damage by not applying insecticides.

olds for treating ants and use of selective bait instead of broadcast spraying.

Total insect damage was greatest in BIOS orchards during 1996, averaging $7.13 \%$, compared with $3.89 \%$ in conventional orchards. Total damage in 1997 averaged $2.96 \%$ for BIOS orchards and $2.84 \%$ for conventional. Total damage in 1998 averaged $4.97 \%$ in BIOS and $4.00 \%$ in conventional orchards. Although no significant difference in total damage was found between the two practices, many growers perceive that eliminating sprays will result in too much damage, as experienced in the unsprayed orchards in 1996.

A survey conducted by CAFF with different BIOS growers during 1996 and 1997 verified the results of our study (M. Stevenson, unpublished). In 1996, 13 BIOS almond growers in Merced County and 12 in Stanislaus County provided grade sheets from processors that indicated insect infestation. In 1997, nine BIOS growers in Merced County and 10 in Stanislaus County did the same. The infestations were then compared to the county averages, as reported in the Almond Board of California's 1997 and 1998 annual yield and damage summary. One of the four comparisons resulted in significantly more damage than the county average $(4.3 \%$ for Merced County BIOS growers versus $2.5 \%$ for the countywide average in 1996).
However, in all cases the BIOS growers experienced more damage than the county average.

Although the differences in damage may seem small to those not involved in producing almonds, many growers are unwilling to risk higher levels of damage. Until reliable predictive techniques are identified and reasonably effective nondisruptive control methods developed, many growers will not stop applying the broad-spectrum insecticides. It is important for the almond industry to continue demonstrating to farmers and pest control advisers the success of new programs as they are implemented.

W.J. Bentley is IPM Entomologist, UC Kearney Agricultural Center; L.

Hendricks is Farm Advisor, Merced County; R. Duncan is Farm Advisor, Stanislaus County; C. Silvers was Lab Assistant, UC Kearney Agricultural Center; L. Martin is Staff Research Assistant, UC Kearney Agricultural Center; M. Gibbs was Research and Documentation Coordinator, BIOS, Community Alliance with Family Farmers; and M. Stevenson was BIFS Coordinator, UC Sustainable Agriculture Research and Education Program. The authors thank the Almond Board of California, California Department of Pesticide Regulation and cooperating growers: Glenn Arnold, Golvert Balvert, Dan Baptista, Bruce Beekman, Sherman Boone,
Mike Bragga, Fritz Helzer, Leonard Kinoshita, Robert Lambrix, Sandra Madsen, Galen Miyamoto, Lane Parker, Chuck Segers and Ivan and Scott Stinson.

\section{References}

Barnes MM, Barnett WW, Kester DE, et al. 1985. Integrated Pest Management for Almonds. UC Statewide Integrated Pest Management Project, UC DANR Pub 3308. $156 \mathrm{p}$

Bentley WJ, Hendricks L, Duncan R, et al. 1998. The use of San Jose scale monitoring techniques in establishing a relationship between spring male scale populations and spring crawler abundance in almonds: Interim report. UC Cooperative Extension/Kearney

Plant Protection Group. Plant Protection Quarterly 8(3-4):4-6.

Hendricks LC. 1995. Almond growers re duce pesticide use in Merced County field trials. Cal Ag 49(1):5-10.

Rajotte EG, Kazmierczak RF Jr, Norton GW, et al. 1987. The National Evaluation of Extension's Integrated Pest Management (IPM) Programs, Appendix 2: California Almond IPM Impact Study. Virginia Cooperative Extension Service Pub 491-013, July. 40 p.

Santer L. 1995. BIOS for Almonds: $A$ Practical Guide to Biologically Integrated Orchard Systems Management. Community Alliance with Family Farmers Foundation and the Almond Board of California, Davis, CA. $104 \mathrm{p}$.

Swezey SL, Broome JC. 2000. Growth predicted in biologically integrated and organic farming. Cal Ag 54(4):26-35.

Zalom FG, Van Steenwyk RA, Bentley WJ, et al. 2001 revised. Almond Pest Management Guidelines, UC DANR Pub 3339. Oakland, CA.

Zalom FG, Weakley C, Hendricks LC, et al. 1984. Cultural management of the navel orangeworm by winter sanitation. $\mathrm{Cal} \mathrm{Ag}$ 38(3-4):28. 